\title{
Kurumsal Yönetim Endeksinde Yer Almanın Mevduat Bankalarının Performansına Etkisi: BİST Örneği ${ }^{1}$
}

DOI NO: 10.5578/JSS.7204

Veysel Kula ${ }^{2}$

Ender Baykut ${ }^{3}$

Özet

Bu çalışmada, mevduat toplayan bankaların Kurumsal Yönetim Endeksinde yer almalarının finansal performanslarına olan etkisi araştırılmıştır. Bu amaçla, 2012 sonu itibarl ile BISST bünyesinde işlem gören ve beşi Kurumsal Yönetim Endeksinde yer alan mevduat toplayan toplam 14 ticari bankanın 2007-2012 verileri kullanılarak panel veri analizi gerçekleştirilmiştir. Analiz sonucu, endekste yer almak ile piyasa değeri arasında istatistiksel olarak anlaml bir ilişki saptanamamıştır. Bankaların piyasa değeri ile aktif karlılı̆̆l ve özsermaye büyüklüğü arasında pozitif, piyasa değeri ile mevduat büyüklüğü arasında ise negatif ilişki vardır.

Anahtar Kelimeler: Borsa İstanbul, Panel Veri Analizi, Kurumsal Yönetim Endeksi, Banka Performansi

\section{Impact of Listing in Corporate Governance Index Upon the Performance of Depository Banks: A Case of BIST}

\footnotetext{
Abstract

This study aims at investigating the impact of listing in Corporate Governance Index on the performance of depository banks. For that purpose, panel data regression is used in analyzing the data of 14 depository banks, with the five in Corporate Governance Index as of the end of 2012, all listed on BIST. Results of the study reveal that there is no statistically significant relationship between market value and getting listed in the Index. Market value is positively related to return on

Bu yayımın hazırlanmasında TÜBA desteğinden yararlanılmıştır.

2 Prof. Dr., Afyon Kocatepe Üniversitesi, İktisadi ve İdari Bilimler Fakültesi, Uluslararası Ticaret ve Finansman Bölümü. kula@aku.edu.tr

3 Araştırma Görevlisi, Afyon Kocatepe Üniversitesi, İktisadi ve İdari Bilimler Fakültesi, İngilizce İşletme Bölümü. ebaykut@aku.edu.tr
} 
equity and equity volume whereas there is a negative relationship between market value and deposit volume.

Key Words: Borsa Istanbul, Panel Data Analysis, Corporate Governance Index, Bank Performance

\section{Giriş}

Finans sektörünün itici gücü olan bankacılık sektörü, tasarrufların ekonomiye yönlendirilip farklı birimlerin finansman ihtiyacinın karşılanmasında önemli bir rol oynamaktadır. Bankacılık Düzenleme ve Denetleme Kurulu (2013) verilerine göre Aralık 2013 itibarı ile Türkiye’de söz konusu rolü yerine getiren mevduat toplama yetkisine sahip 34 tane banka vardir. Mevduat toplama yetkisi olan bu bankalardan 14 tanesi Borsa İstanbul (BİST) bünyesinde işlem görmektedir. BİST bünyesindeki mevduat toplama yetkisine sahip 14 bankanın Aralı 2013 sonu itibarı ile 6 tanesi Kurumsal Yönetim Endeksinde (XKURY) yer almaktadır.

$\mathrm{Bu}$ çalışmanın amac1, BİST bünyesinde işlem gören bankaların Kurumsal Yönetim Endeksine girmelerinin finansal performanslarına olan etkisini ortaya koymaktır. Endeks, kurumsal yönetim ilkelerinin uygulanma derecesinin bir göstergesidir. BİST bünyesinde 2007 y1lında endeks olarak hukuki ve fonksiyonel bir form haline gelen kurumsal yönetim yaklaşımının ivmelenmiş gelişimi yakın geçmişte gerçekleşmiştir. Kurumsal yönetim ile ilgili yerleşik bir tanım Shleifer ve Vishny (1997:737) tarafından "şirketlere fon sağlayan yatırımcıların, yatırımlarını geri alabilmeleri için şirketlerin uyması gereken kurallar ve yöntemler" olarak verilmiştir. Geniş anlamda kurumsal yönetim; modern yaşamda bir amaca ulaşmak için şirket yönetimi ile toplumun ilişkilerini düzenleyen ve iyi şirket yönetimi için gerekli resmi ve resmi olmayan kurallar bütünü olarak tanımlanabilirken (Aktan, 2006:5; TÜSİAD,2002:9 ; Aysan, 2007:18) dar anlamda odaklanma şirket hissedarları üzerindedir. Bu kapsamda, kurumsal yönetim şirket yönetimi ile hissedarlar ve paydaşlar arasındaki ilişkileri düzenleyen, hissedarların haklarının şirket tarafından tanınmasına olanak sağlayıp, bu haklarının etkin şekilde kullandırılmasına yardımcı olan ve uzun vadede hissedarlarına ekonomik değer yaratmaya imkân sağlayan her türlü kanun, yönetmelik, kod ve uygulamalardır (Aktan, 2006:2; Aysan,2007:18; Güçlü, 2010:21; TKYD, 2011:13; TÜSİAD, 2002:9).

Kurumsal yönetimin işlevsel ifadesi olarak ilkelerinin saptanmasına yönelik ilk uluslararası nitelikli çalışma 1999 yılında OECD Kurumsal Yönetim İlkeleri olarak ortaya çıkmıştır. Eylül 1999'da Türkiye Bankalar Birliği bünyesinde faaliyet gösteren Basel Bankacılık Gözetim Komitesi tarafından hazırlanan ve kurumsal yönetim açısından Türkiye'de yapılan ilk kurumsal çalışma olan "Bankalarda Kurumsal Yönetim” isimli rapor da 
OECD ilkelerini esas almıştır (TBB, 1999:3). Takiben, TÜSİAD çatısı altında oluşturulan Kurumsal Yönetim Çalışma Grubu 2002 Yılında "Kurumsal Yönetim: En İyi Uygulama Kodu" çalışmasını, Sermaye Piyasası Kurulu da 2003 y1lında "SPK Kurumsal Yönetim İlkeleri”ni yayınlamıştır.

Sermaye Piyasası Kurulu, kurumsal yönetim ilkelerini 2005 ve 2010 yıllarında uluslararası gelişmeleri dikkate alarak güncellemiştir. "Uygula ya da açıkla" prensibini esas alan SPK Kurumsal Yönetim İlkeleri ile uyumun bir beyan halinde duyurulması zorunluluğu 2004 yılında Türk şirketlerinin hayatına girmiştir. 2005 yılında ise Kurumsal Yönetim Uyum Beyanları'na y1llık faaliyet raporlarında yer vermek mecburi hale getirilmiştir (TKYD, 2011:21-22). Sermaye piyasalarında kurumsal yönetim açısından yaşanan hızlı gelişmeler Kurumsal Yönetim Endeksi (XKURY)'nin 2007 yılında hayata geçirilmesi ile devam etmiştir.

Borsa İstanbul (BİST) Kurumsal Yönetim Endeksi'nin (XKURY) amacı, payları BIST pazarlarında (Gözaltı Pazarı ve C Listesi hariç) işlem gören ve kurumsal yönetim ilkelerine uyum notu 10 üzerinden en az 7 olan şirketlerin fiyat ve getiri performansının ölçülmesidir. Kurumsal Yönetim İlkelerine uyum notu, SPK tarafından belirlenmiş derecelendirme kuruluşları listesinde bulunan derecelendirme kuruluşlarınca, şirketin tüm kurumsal yönetim ilkelerine bir bütün olarak uyumuna ilişkin yapılan değerlendirme sonucunda verilmektedir (BİST, 2013).

31.08.2007 tarihinde yalnızca 5 şirket ile hesaplanmaya başlanan XKURY'da yer alan şirket sayısı Aralık 2013'te 46'ya ulaşmıştır. Bu 46 şirketin arasında 6 tane de mevduat toplayan ticari banka yer almaktadır. BISST'de koteli olup da XKURY'de yer almayan mevduat toplayan banka sayısı ise sekizdir. Mevcut çalışma, BİST'de koteli olan mevduat toplayan ticari bankaları XKURY'de yer almalarının finansal performanslarını etkileyip etkilemediğini ortaya koymayı hedeflemektedir. Literatür incelemesinde BIST bünyesinde kurumsal yönetim endeksinde yer almanın banka performansına olan etkisini panel veri analizi ile ele alan bir çalışmaya saptanmamıştır. $\mathrm{Bu}$ nedenle mevcut çalışma literatüre orijinal bir katk1 sağlamaktadır.

Çalışmanın takip eden bölümünde kurumsal yönetim ile şirket performansı arasındaki ilişkiyi ortaya koyan literatür araştırmasına yer verilmiştir. Çalışmanın ikinci bölümünde metodoloji ve kullanılan veri hakkında bilgi verilmiştir. Üçüncü bölümde analiz sonuçları verilmiştir. Çalışma bulgu yorumlarını içeren dördüncü bölüm ile sona ermektedir. 


\section{1- Kurumsal Yönetim ve Şirket Performansı Üzerine Yapılan Çalış̧malar}

Kurumsal yönetim endeksinde yer almanın şirketlerin performansı üzerine etkisini araştıran çalışmalar farklı sonuçlar ortaya koymuştur. Sherman (2004:6) tarafından ifade edildiği gibi; kurumsal yönetim endeksine girip kurumsal yönetim uygulamalarına özellikle de şeffaflığa büyük önem vererek şirketler, kısa vadede yatırımcının güvenini kazanıp uzun vadede daha fazla getiri elde etmeyi ve yatırımcıların güveninden dolayı sermaye maliyetini azaltmayı amaçlamaktadırlar. Nitekim literatür araştırması bu saptamayı doğrulayan sonuçlar da içermektedir. Örneğin 1990'lı y1llarda 24 farklı kurumsal yönetim göstergesini kullanarak Amerika'da 1500 şirketten oluşan bir kurumsal yönetim endeksi oluşturan Gompers vd. (2003:144-145), bu endeksteki şirketlerin değeri ve endeksin getiriler üzerine performanslarını incelemişlerdir. Bu çalışmanın sonuçlarına göre; kurumsal yönetim endeksi puanı düşük olan hisse senetlerini satıp yüksek olan hisse senetlerini alan bir yatırımeı daha fazla getiri elde edebilmektedir.

Karamustafa vd. (2009) ise yapmış oldukları çalışmada kurumsal yönetim ile şirket performansı arasındaki ilişkiyi incelemiştir. 2009 yılında yapılan çalışmada endekste yer alan 12 şirketten 8 'inin verilerine ulaşarak gerekli analizler yapılmış ve analizlerin sonuçlarına göre; aktif devir hızı, aktif kârlılığ1 ve öz sermaye kârlılığ1 performans göstergelerinde endekse girmeden önce ve endekse girdikten sonra anlamlı farklılıklar ortaya çıkmıştır. Diğer performans göstergeleri için (cari oran, borç oranı, finansal kaldıraç derecesi, net kar marjı ve faaliyet kar marjı) ise endeks kapsamı öncesi ve sonrası için anlamlı bir farklılık ortaya çıkmamıştır. Bu sonuçlara göre XKURY kapsamındaki şirketlerin performanslarında endekse giriş sonras1 kısmen de olsa artış olduğu görülmüsstür.

Șengür ve Püskül (2011), 2009 y1lı sonunda Kurumsal Yönetim Endeksi'nde yer alan 24 şirketin, yönetim kurulu yapısı ve finansal performansları arasındaki ilişkiyi t testi ile incelemiştir. Çalışmada, finansal performansın ölçülmesi amacıyla varlık getiri oranı, özkaynak getiri oranı, fiyat kazanç oranı ve hisse başı kar göstergeleri kullanılmıştır. Analiz sonuçlarına göre, yönetim kurullarında bağımsız yönetim kurulu üyesi bulunan şirketlerin varlık getiri oranı ile özkaynak getiri oranlarının daha yüksek olduğu ortaya çıkmıştır.

Dalğar ve Çelik (2011) yaptıkları çalışmada, XKURY kapsamında yer alan imalat sektörü işletmelerinin endekse girmeden önceki (2006) ve endekse girdikten sonraki (2009) döneme ait finansal oranlarını, bulundukları sektörün ortalamaları ile karşılaştırmışlardır. Analiz sonuçlarına göre, işletmelerin faaliyet ve karlılık oranları açısından endekse 
girdikten sonra sektör ortalamalarına göre daha iyi performans gösterdikleri gözlenmiştir.

Sakarya (2011) ise çalışmasında, hisse senetleri BİST'de ișlem gören ve 2009 yılında kurumsal yönetim derecelendirme notu alarak XKURY kapsamına alınan 11 şirketin derecelendirme notunun ilanı ile hisse senedi getirileri arasındaki ilişkiyi incelemiştir. Olay çalışması yöntemi kullanılarak yapılan analizin sonucuna göre kurumsal yönetim derecelendirme notunun ilanı ile hisse senedi getirisi arasında pozitif bir ilişkinin olduğunu tespit edilmiştir.

Gökçen vd. (2012), tarafından yapılan çalışmada 2010 yılında Kurumsal Yönetim Endeksi'nde yer alan 24 şirket ile İMKB 50'de yer alan ve verilerine ulaşılabilen 29 şirketin verileri karşılaştırılmıştır. Çalışmanın sonucuna göre, Kurumsal Yönetim Endeksi'nde yer almanın, bir performans ölçütü olarak piyasa değeri artışılyla anlamlı ilişkisi olduğu tespit edilmiştir.

Yenice ve Dölen (2013) tarafindan yapılan çalışmada ise, XKURY endeksinde yer alan 37 şirketin 2007-2011 yılları arasında derecelendirme notlarının aç1klanma tarihinden 30 gün önce ve 30 gün sonraki borsa değerleri tespit edilmiş ve Wilcoxon İşaretli Sura Sayılar ve $t$ testi ile karşılaştırmaları yapılmıştır. Analiz sonucuna göre, derecelendirme notu ile şirketin borsa değeri arasında anlamlı bir ilişkinin varlığ 1 tespit edilmiştir.

$\mathrm{Bu}$ çalışmalar aksine, kurumsal yönetim endeksinde yer almanın şirket performansı üzerine herhangi bir etkisi olmadığı sonucuna ulaşan çalışmalar da vardır. Örneğin Karayel ve Gök (2009), kurumsal yönetim uygulamalarının şirket performansı üzerine etkisini ölçmek için 2009 yılında XKURY'de işlem gören 9 şirketin endekse girmeden 5 çeyrek dönem öncesi ve endekse girdikten 4 çeyrek dönem sonraki hisse başına kar, varlık karlılı̆g ve fiyat kazanç oranlarını incelemiştir. Analiz sonucuna göre; kurumsal yönetim uygulamaları ile finansal performans arasında bir ilişki bulanmadığı saptanmıştır.

Kalayc1 vd. (2009) ise ARCH-GARCH modellerini kullanarak yaptıkları analizde İMKB-100 'de işlem gören şirketler ile XKURY'de işlem gören şirketlerin salt getirileri karşılaştırmışlardır. Yapılan çalışma sonucunda kurumsal yönetim ilkelerine uyum ile şirket performansı arasında ilişkinin bulunmadığ 1 ortaya çıkmıştır.

Dağlı vd. (2010) çalışmalarında Kurumsal Yönetim Endeksi de dâhil olmak üzere endekslerdeki bütün şirketlerin 2007 Eylül-2009 Kasım döneminde risk-getiri açısından değerlendirmesi yapmıștır. Çalışmada, portföy performans değerlendirmesinde yaygın olarak kullanılan Sharpe, Treynor ve Jensen performans endekslerine yer verilmiştir. Yapılan analiz sonucunda; çalışmadaki Kurumsal Yönetim Endeksi de dâhil endeksler 
kapsamında yer alan işletmelerin yatırımcılarına ek bir gelir sağlamadığı sonucuna ulaşılmıştır.

Kılıç (2011) ise 2010 yılı Ekim ayında BİST XKURY'de yer alan 28 şirketin geçer not alarak endekse girdikleri tarih ve hemen sonrasında hisse senetlerinin fiyatlarının olumlu olarak etkilenip etkilenmediğini test etmiştir. Çalışma sonuçlarına göre, endekste yer alan şirketlerin yalnızca \%60'ının ilk birkaç gün içinde yatırımcısına pozitif getiri sağladığı ancak bu hisse senetlerinden 2 tanesi dişında getirilerin önemli boyutta olmadığ 1 tespit edilmiştir.

Çonkar vd. (2011) XKURY'de işlem görmekte olan, 2007 yılında 7 ve 2008 yılında 10 halka açık büyük ölçekli firmaların verileri üzerinde araştırma yapmışlardır. Analiz kapsamında finansal performans göstergesi olarak seçilen 8 finansal oran (net kar marjı, brüt kar marjı, özsermaye karlılığg1, kaldıraç oranı, yatırım karlılığ1, cari oran, borç/özsermaye, fiyat kazanç oranı) 2007 ve 2008 yılları için ayrı ayrı hesaplanarak ve her bir yıl için şirket performanslarına göre TOPSIS yöntemi ile sınanmış ve sıralanmıştır. Ayrıca, inceleme dönemdeki işletmelerin finansal performansları ölçülerek kurumsal yönetim derecelendirme notları ile karşılaştırılmıştır. Analiz sonucuna göre, derecelendirme notları yüksek olan şirketlerin finansal performanslarının yüksek olmadığ 1 tespit edilmiştir.

Ege vd. (2013) ise yaptıkları çalışmada 2009-2011 yılları arasında BİST XKURY'de yer alan 18 şirketin derecelendirme notları ile finansal performanslarını TOPSİS yöntemiyle incelemişlerdir. Elde edilen sonuçlara göre, kurumsal yönetim derecelendirme notları ile finansal performansların aynı yönde hareket etmediği sonucuna ulaşılmıştır.

Acar vd. (2013) ise, XKURY'de yer alan 40 şirketin endekste yer almalarıyla birlikte hisse senetlerinde normalüstü getiri elde edilip edilmediğini incelemişlerdir. Çalışmada olay çalışması yöntemi kullanılmış olup; cari, likidite, kısa vadeli borç oran1, kaldıraç oran1, nakit oran1, dönem net karı/ toplam aktif ve piyasa değeri/defter değeri oranları analize konu olmuştur. Analiz sonuçlarına göre; kurumsal yönetim endeksinde işlem görmeye başlayan şirketlerin hisse senedi fiyatlarında anormal getiriler gözlemlenmemiştir.

Literatür araştırması sonuçları çerçevesinde çalışmaların bir kısmında kurumsal yönetimin şirket performansı üzerine herhangi bir etkisi saptanmamıştır. Buna karşın daha fazla sayıda çalışmada ise endekste yer almak ile şirket performansı arasında olumlu sonuç ortaya konmuştur. Sherman'1n (2004:6) kurumsal yönetim endeksine girerek şirketlerin kısa vadede yatırımcının güvenini kazanarak bunu uzun vadede daha fazla getiri elde etmeleri saptaması da dikkate alındığında mevcut çalışmada beklenti 
endekste yer almak ile şirket performansı arasında olumlu ilişki olması şeklindedir.

\section{2- Çalışmanın Metodolojisi ve Veriler}

Ampirik çalışmalarda kullanılan veri türleri üç gruba ayrılmaktadır: zaman serileri (time series), yatay kesit verileri (cross-section) ve panel veriler. Zaman serileri verileri, bir ya da daha fazla değişkenin belirli bir zaman dilimindeki gözlenen değerlerini içerir. Yatay kesit verileri, aynı zaman noktasında birkaç örneklem biriminin bir ya da daha fazla değişken için değerlerini ele alır. Panel verilerde ise, aynı yatay kesit birimlerinin zaman içerisindeki değişimi analiz edilir. Kısacası panel veriler, hem zaman hem de mekân boyutlarını içermektedir (Gujarati, 2004:636).

Panel veri analizi modelinin genel formülü şu şekilde yazılabilir:

$$
\begin{aligned}
& Y_{i t}=\beta_{1 i t}+\beta_{2} X_{2 i t}+\beta_{3} X_{3 i t}+\cdots+\beta_{n} X_{n i t}+u_{i t} \\
& i=1,2,3, \ldots . \mathrm{n} \\
& t=\text { veri dönemi }
\end{aligned}
$$

Panel regresyon formülünde değişkenler yatay kesit birimini $(i)$, ve zaman periyodunu $(t)$ göstermektedir. Bu şekilde maksimum $\mathrm{N}$ adet yatay kesit birimi ve $\mathrm{T}$ adet zaman dilimi söz konusu olmaktadır. Eğer her bir yatay kesit birimi aynı sayıda zaman serisi gözlemine sahip ise dengeli panel (balanced panel), eğer yatay kesit birimlerinin zaman serisi gözlemleri farklı sayıda ise panel için dengesiz panel (unbalanced panel) olarak adlandırılır. Çalışmada 14 adet bankanın (yatay kesit) 6 yıllık döneme ilişkin yıllık verileri (dikey kesit) eksiksiz analizde yer aldığ 1 için dengeli panel veri analizi kullanılmıştır.

Çalışmada, 2012 yılı sonu itibarı ile BİST bünyesindeki bulunan Kurumsal Yönetim Endeksi'ndeki beş ve bu endeks dışındaki dokuz olmak üzere toplam 14 mevduat toplayan bankanın finansal performansı panel veri regresyon yöntemi ile incelenmiştir. Analize konu olan bankaların listesi Tablo 1'de gösterilmiştir. XKURY'de yer alan mevduat bankalarının endekse hangi yıl girdikleri parantez içerisinde belirtilmiştir. 
Tablo 1. Analize Konu Olan Bankaların Listesi

\begin{tabular}{|c|c|}
\hline XKURY'de Yer Alan Bankalar* & XKURY'de Yer Almayan Bankalar \\
\hline Bank Asya (2008) & Garanti Bankası \\
\hline Yapı Kredi Bankası (2008) & İş Bankası \\
\hline Şekerbank (2009) & Finansbank \\
\hline Albaraka (2010) & Vakıfbank \\
\hline Halk Bankası (2010) & Akbank \\
\hline \multirow{2}{*}{} & Tekstilbank \\
& Türkiye Ekonomi Bankası \\
\cline { 2 - 2 } & Alternatifbank \\
\cline { 2 - 2 } & Denizbank \\
\cline { 2 - 2 } & \\
&
\end{tabular}

*Parantez içindeki tarihler bankaların endekse giriş yıllarıdır.

2007 y1lında kurulan Kurumsal Yönetim Endeksine ilk giren bankalar Yap1 Kredi ve Bank Asya'dır. Bu bankalar endekse 2008 yılında derecelendirme notu alarak girmişlerdir. Daha sonra 2009 yılında Şekerbank, 2010 yılında Albaraka ve Halk Bankası endekse dâhil olmuştur. Ocak 2014 itibariyle endekse giren en son banka Akbank’tır. Çalışmada kullanılan veriler; endeksin hesaplanmaya başladığı yıl olan 2007 ile bankaların konsolide mali tablolara ulaşılabilen en son yıl olan 2012 arasındaki döneme aittir. Veriler bankaların yıllık faaliyet raporlarından derlenmiștir. Faaliyet raporlarına Kamuyu Aydinlatma Platformu'nun web sayfasindan (www.kap.gov.tr) verilen bağlantı ile ulaşılmıştır.

Borsa İstanbul'da koteli mevduat toplayan bankaların Kurumsal Yönetim Endeksi'nde yer almalarının finansal performans üzerine etkisini ele alan çalışmada panel veri analizi kullanılmıştır. 2012 sonu itibarı ile endekste olan 5 banka ile endekste bulunmayan 9 bankanın verilerinin kullanıldığı çalışmada bankaların piyasa değeri bağımlı değişken olarak seçilmiştir. Çalışmada endekste olma kukla değişken olarak belirtilmiştir ("0" endekste olmamay1, " 1 " ise endekste olmay1 temsil etmektedir). Analizde yer alan diğer bağımsız değişkenler ise aktif karlılığı, mevduat büyüklüğü, özkaynak büyüklüğü ve kredi büyüklüğüdür. Analizde yer alan değişkenler bankalar üzerine yapılan daha önceki çalışmalarda da kullanılmıştır. Örneğin, Yıldız (2010) ve Bektaş ve Tekin (2013) finansal performans ölçümü olarak piyasa değerini kullanmışlardır. Ayrıca aktif karlılığı (Çelik ve Akarım, 2012; Demirel vd. 2013; Bektaş ve Tekin, 2013), 
mevduat büyüklüğ̈̈ (Doğru, 2011; Sakarya ve Kaya, 2013), özkaynak büyüklüğü (Bektaş ve Tekin, 2013) ve kredi büyüklüğü de (Doğru, 2011; Bektaş ve Tekin, 2013; Sakarya ve Kaya, 2013) önceki çalışmalarda yer alan oranlardir.

Panel veri analizinde kullanılan bağımlı değişken ve beș adet bağımsız değişkenin tanımlaması ile beraber her bir bağımsız değişkenin bağımlı değişken üzerine beklenen etkisi aşağıdaki Tablo 2'de verilmiştir:

Tablo 2. Değişkenlerin Açıklanması

\begin{tabular}{|c|c|c|}
\hline Değişken & Açıklama & $\begin{array}{l}\text { Bağımlı } \\
\text { Değiş̧ken ile } \\
\text { Beklenen } \\
\text { İlişki }\end{array}$ \\
\hline $\begin{array}{l}\text { Piyasa Değeri } \\
\text { (PD) }\end{array}$ & $\begin{array}{l}\text { Bankaların, birim hisse senedi piyasa değeri } \\
\text { ile toplam hisse senedi sayısının çarpımı ile } \\
\text { hesaplanmıştır. }\end{array}$ & \\
\hline $\begin{array}{l}\text { Endekste } \\
\text { Olma(EO) }\end{array}$ & $\begin{array}{l}\text { Bankaların endekste olup olmadıklarının } \\
\text { temsili için } 0-1 \text { değerleri verilmiştir. (" } 0 \text { " } \\
\text { endekste olmamayı, " } 1 \text { " ise endekste olmayı } \\
\text { temsil etmektedir.) }\end{array}$ & + \\
\hline $\begin{array}{l}\text { Mevduat } \\
\text { Büyüklüğ̈̈/ } \\
\text { Aktifler (M/A) }\end{array}$ & $\begin{array}{lll}\text { Bankaların topladıkları mevduat tutarının } \\
\text { toplam aktiflere } & \text { oranlaması ile } \\
\text { hesaplanmıştır. } & \end{array}$ & + \\
\hline $\begin{array}{l}\text { Özsermaye/ } \\
\text { Aktifler(Ö/A) }\end{array}$ & $\begin{array}{l}\text { Bankaların sahip olduğu özkaynaklarının } \\
\text { toplam aktif tutarına oranlanması ile } \\
\text { hesaplanmıştır. }\end{array}$ & + \\
\hline $\begin{array}{l}\text { Aktif Karlılık } \\
\%(\text { ROA) }\end{array}$ & $\begin{array}{l}\text { Bankaların elde etmiş oldukları net karın, } \\
\text { toplam aktif tutarına oranlanması ile } \\
\text { hesaplanmıştır. }\end{array}$ & + \\
\hline $\begin{array}{l}\text { Krediler / } \\
\text { Aktifler (K/A) }\end{array}$ & $\begin{array}{l}\text { Bankaların vermiş olduğu kredilerin toplam } \\
\text { aktif tutarına oranlanması ile bulunmuştur. }\end{array}$ & + \\
\hline
\end{tabular}

Literatür araştırmasında da ortaya konduğu üzere, önceki çalışmaların önemli bir kısmında (örneğin Karamustafa, 2009; Sengür ve Püskül, 2011; Dalğar ve Çelik, 2011; Gökçen,2012) endekste yer almak ile şirket performansı arasında olumlu sonuç çıktığı için mevcut çalışmada da bu iki değişken arasında pozitif ilişki beklentisi vardır. Benzer şekilde mevduat büyüklüğü ile piyasa değeri arasında olumlu ilişki bulan çalışmalar (örneğin 
Y1ld1z, 2010; Doğru, 2011) olduğundan dolay1 mevcut çalışmada mevduat büyüklüğünün bankaların piyasa değerini olumlu etkilemesi beklenmiștir.

Özkaynak büyüklüğü-finansal performans (Sakarya ve Kaya, 2013; Doğru, 2011;Bektaş ve Tekin, 2013), aktif karlılı̆̆1-finansal performans (Karamustafa, 2009; Sengür ve Püskül, 2011) ve kredi büyüklüğü-finansal performans (Doğru, 2011) ilişkilerini analiz eden çalıșma sonuçları dikkate alındığında söz konusu değişkenler ile bağımlı değişken arasındaki ilişki beklentisi pozitif yönlüdür.

Kullanılan değişkenlerin tanımlayıcı istatistikleri ise Tablo.3'te gösterildiği gibidir:

Tablo 3. Zaman Serisinin Tanımlayıcı İstatistikleri

\begin{tabular}{|l|c|c|c|c|c|}
\hline & Ort. & Medyan & Max. & Min. & $\begin{array}{l}\text { Std. } \\
\text { Sapma }\end{array}$ \\
\hline Piyasa Değeri (log) & 9,64 & 9,79 & 10,58 & 8,30 & 0,64 \\
\hline Endekste Olma & 0,23 & 0,00 & 1,00 & 0,00 & 0,42 \\
\hline $\begin{array}{l}\text { Mevduat } \\
\text { Büyüklüğü/Aktifler(\%) }\end{array}$ & 65,47 & 64,14 & 85,18 & 48,57 & 8,01 \\
\hline Özsermaye /Aktifler \% & 12,07 & 11,98 & 21,94 & 7,14 & 2,38 \\
\hline Aktif Karl111k \% & 1,81 & 1,75 & 3,54 & 0,43 & 0,69 \\
\hline $\begin{array}{l}\text { Krediler/ } \\
\text { Aktifler \% }\end{array}$ & 62,00 & 61,73 & 76,52 & 41,67 & 8,83 \\
\hline
\end{tabular}

Tablo.3'ten de görüleceği üzere analizde yer alan şirketlerin piyasa büyüklüğü logaritmik değer olarak 8,30-10,58 aralığında yer alıp ortalama 9,64 değerine sahiptir. Mevduat büyüklüğü ortalaması \%65,47 iken özsermaye büyüklüğü \%12,07 ortalamaya sahiptir. Kredilerin büyüklüğü ise ortalama olarak \%62 değere sahip iken aktif karlılığı ortalaması da $\% 1,81$ 'dir.

\section{3- Bulgular ve Tartışması}

Çalışmada yer alan beş adet bağımsız değişken arasında çoklu korelasyon olup olmadığının araştırılması için korelasyon analizi yapıllmıştır. Aşağıdaki Tablo.4'de görüldüğü üzere bağımsız değişskenler arasında yüksek korelasyon gözlemlenmemiştir. 
Tablo 4. Bağımsız Değişkenler Arasındaki Korelasyon

\begin{tabular}{|l|l|l|l|l|l|}
\hline & $\begin{array}{l}\text { Endekste } \\
\text { Olma }\end{array}$ & M/A & Ö/A & ROA & K/A \\
\hline Endekste Olma & 1,00 & & & & \\
\hline M/A & 0,32 & 1,00 & & & \\
\hline O/A & 0,01 & 0,04 & 1,00 & & \\
\hline ROA & $-0,02$ & 0,16 & 0,09 & 1,00 & \\
\hline K/A & 0,27 & 0,32 & 0,10 & $-0,32$ & 1,00 \\
\hline
\end{tabular}

(MA: Mevduat Büyüklüğ̈̈, Ö/A: Özsermaye /Aktifler (\%), ROA: Aktif Karlılık (\%), K/A: Krediler/Aktifler (\%))

Panel veri analizinde iki alternatif bulunmaktadır: sabit-etkiler panel veri analizi ve rassal-etkiler panel veri analizi. Sabit-etkiler panel veri analizinde her bir yatay kesit birimi için kukla değişkenler aracılığ ile farklı sabit terim hesaplanır. Bu tür panel veri tek-yönlü sabit-etkiler panel veri olarak isimlendirilir. Eğer sadece yatay kesit birimleri için değil de her bir dikey kesit birimi için de sabit terim hesaplanırsa çift-yönlü sabit-etkiler panel veri kullanılmış olur. Eğer birimlere ilişkin sabit terimin evrenden rassal olarak saptandığı varsayılırsa bu yöntem rassal-etkiler panel veri analizi olarak bilinir.

Panel veri analizlerinde sabit-etkiler veya rassal-etkiler modellerin seçimine yönelik olarak Brooks (2008:500) "eğer örneklemdeki birimler tüm evren birimlerini içeriyorsa sabit-etkiler panel veri analizi"nin kullanılmasının uygun olacağını belirtmektedir. Mevcut çalışma da 2012 sonu itibarı ile BİST'de işlem gören toplam 14 mevduat toplayan bankanın hepsini kapsadığ 1 için sabit-etkiler panel veri analizi kullanılmıştır. Nitekim analiz sonucunda gerçekleștirilen Sabit-etkiler Likelihood Ratio testi sonuçları model seçimi uygunluğunu teyit etmektedir (yatay kesit $\mathrm{F}$ ve Chi Square'in her ikisi için de $\mathrm{p}<0,0000)$. Çalışmada ayrıca yatay kesit birimlerinin sabit terimlerine odaklanan tek-yönlü sabit etkiler panel veri analizi kullanılmıştır (çift-yönlü sabit-etkiler panel veri analizi sonuçlarının bulguları da aynı çıkmış olup ayrıca raporlanmamıştır).

Çalışmada kullanılan panel veri analizi modelinin formülü ise şu şekilde yazılabilir: 


\section{LogPiyasa Değgeri $i_{i t}=\beta_{1 i}+\beta_{2}$ Endekste Olma $i t+$} $\beta_{3}$ Mevduat Büyüklüğü/Aktifler $_{i t}+\beta_{4}$ Özsermaye / Aktifler $_{i t}+\beta_{5}$ Aktif Karlllık $_{i t}+\beta_{6}{\text { Krediler } / \text { Aktifler }_{i t}}+u_{i t}$

$i=1,2,3, \ldots .14$ (verisi analiz edilen banka sayıs1)

$t=2007,2008,2009 \ldots 2012$ (veri dönemi)

Sabit-etkiler panel veri regresyon analizi E-Views 8 programı ile gerçekleştirilmiş̧tir. Regresyon sonuçları Tablo.5'de yer almaktadır.

Tablo 5. Panel Veri Regresyon Sonuçları

Bağımlı Değişken: LogPiyasaDeğeri

Yöntem: Panel En Küçük Kareler

Dâhil Edilen Dönem: 6 yıl

Dâhil edilen yatay kesit: 14

Toplam dengeli panel gözlem sayıs1: 84

White cross-section standard errors \& covariance (d.f. corrected)

\begin{tabular}{|c|c|c|c|c|}
\hline DEĞİSTKEN & Katsay1 & Std.Hata & t-istatistiği & Olasılık \\
\hline $\mathrm{C}$ & 9.3293 & 0.37199 & 25.0792 & 0.0000 \\
\hline Endekste Olma & 0.0368 & 0.11465 & 0.32161 & 0.7488 \\
\hline Mevduat /Aktifler(\%) & -0.0094 & 0.00405 & -2.34279 & 0.0222 \\
\hline Özsermaye /Aktifler (\%) & 0.0294 & 0.00737 & 3.99851 & 0.0002 \\
\hline Aktif Karl111k (\%) & 0.0782 & 0.02506 & 3.11977 & 0.0027 \\
\hline Krediler/Aktifler (\%) & 0.0068 & 0.00579 & 1.18203 & 0.2415 \\
\hline R-Kare & 0.937 & & & \\
\hline Düzeltilmiş R-Kare & 0.919 & & & \\
\hline Durbin-Watson istatistiği & 2.357 & & & \\
\hline F-istatistiği & 53.741 & & & \\
\hline Olasılık (F-istatistiği) & 0.000 & & & \\
\hline
\end{tabular}

Tablo.5'de yer alan sonuçlara göre bankaların kurumsal yönetim endeksinde yer almalarının piyasa değerlerine herhangi önemli bir etkisi bulunmamaktadır. Piyasa değeri, özsermaye büyüklüğü (t değeri 3,99; $\mathrm{p}<0.00$ ) ve aktif karlılığ1 (t değeri 3,$11 ; \mathrm{p}<0,00$ ) ile istatistiksel olarak anlamlı pozitif ilişki içerisindedir. Piyasa değeri ile mevduat büyüklüğü arasında ise istatistiksel olarak anlamlı negatif ilişki vardır ( $\mathrm{t}$ değeri -2,34; $\mathrm{p}<0,05)$. Kullandırılan kredi tutarı ile piyasa değeri arasında ise herhangi bir anlamlı ilişki çıkmamıştır. 


\section{4- Sonuç}

2003 y1lında SPK Kurumsal Yönetim İlkeleri’nin yürürlüğe girmesi kurumsal yönetim uygulamalarının yaygın ölçekte işlerlik kazanmasının bir ilk adımı olmuştur. Bu gelişimin bir diğer aşaması da kurumsal yönetim endeksinin kurulması ile gerçekleşmiştir. Kurumsal yönetim derecelendirme notu en az 7 olan şirket sayısının $5^{\circ} \mathrm{e}$ ulaşması ile BİST bünyesinde Kurumsal Yönetim endeksi 2007 Ağustos ayında hesaplanmaya başlamıştır.

Çalışma 2012 sonu itibarı ile BİST'te koteli olan 14 mevduat toplayan bankayı ele alıp bankaların Kurumsal Yönetim Endeksinde yer almalarının piyasa değerlerine herhangi bir etkilerinin olup olmadığını ortaya koymayı hedeflemiştir. BİST bünyesinde kurumsal yönetim endeksinde yer almanın banka performansina olan etkisini panel veri analizi ile ele alan daha önce yapılmış bir çalışma saptanmamıştır. Bu nedenle mevcut çalışma literatüre orijinal bir katkı sağlamaktadır.

Analizde piyasa değeri bağımlı değişken olarak, kurumsal yönetim endeksinde olma, mevduat büyüklüğü, özsermaye/aktifler, aktif karlılığ1 ve krediler/aktifler bağımsız değişken olarak belirlenmiştir. Verilerin analizi için tek-yönlü sabit-etkiler panel veri analizi yöntemi kullanılarak, panel regresyon denklemi kurulmuş ve piyasa değerine etki eden değişkenler ortaya çıarılmaya çalışılmıştır.

Analiz sonuçlarına göre piyasa değeri ile kurumsal yönetim endeksinde bulunmak arasında herhangi anlamlı bir ilişki bulunamamıştır. Bu sonuca göre, bankaların kurumsal yönetim endeksinde bulunması, piyasa değeri üzerine herhangi bir etki oluşturmamaktadır. Bir başka deyişle, konu ile ilgili önceki çalışmaların önemli çoğunluğunda ortaya çıkan ve bu çalışma için belirlenen pozitif ilişki analiz sonuçlarında teyit edilmemiştir. Buna rağmen, elde edilen sonuç Karayel ve Gök (2009), Kalaycı vd.(2009), Dağlı vd. (2010), Acar vd. (2013) ve Ege vd.'nin (2013) çalışmalarında elde ettiği sonuçlar ile paralellik göstermektedir. Acar vd.'nin de (2013:140) belirttiği üzere kurumsal yönetim endeksinin bilinirliliğinin düşük düzeyde olması, piyasa değeri ile kurumsal yönetim endeksi arasında herhangi anlamlı bir ilişki bulunmamasının bir nedeni olabilir.

Beklentilere paralel bir şekilde, piyasa değerine istatistiksel olarak anlamlı düzeyde pozitif yönde etki eden değişkenler ise özsermaye büyüklüğü ile aktif karlılık oranıdır. Analiz sonuçlarına göre, bu iki bağımsız değişken piyasa değerini pozitif anlamlı şekilde etkilemektedir. Alternatif varlık kaynağı olan borca göre özsermaye kullanımı piyasa tarafindan olumlu karşılanmaktadır. Aktif karlılık oranı da, bankanın varlıklarını etkin şekilde kullanıp kullanmadığının bir göstergesidir. Varlık kullanım etkinliği şeklinde ifadesini bulan aktif karlılığı da bankaların piyasa değerinin artmasina neden olan bir faktördür. 
Pozitif ilişki beklentisinin aksine, analiz sonuçlarına göre mevduat büyüklüğünün piyasa değeri üzerine istatistiksel olarak anlamlı düzeyde negatif etkisinin olduğu bulunmuştur. Bankacılık sektöründeki rekabet, mevduatlara teklif edilen faiz/getiri oranlarının paralellik gösterip önemli sapmalar içermemesi sonucunu doğurmaktadır. Bu nedenle de, bankalar için piyasa değerlerini arttırmaya yönelik odaklanılacak husus mevduata değil de özsermayeye ağırlık vermek şeklinde ortaya çıkmaktadır. Böylece çalışma bulguları bankacılık sektöründe ekonomik krizlere karşı tampon dokusu oluşturan güvenceli fon kaynağının özsermaye olduğuna da işaret etmektedir.

\section{Kaynakça}

ACAR, M., TEMIZ, H. ve KARAN, M. B., (2013). BİST(Borsa İstanbul) Kurumsal Yönetim Endeksinde (XKURY) Yer Alan Şirketlerin Getiri ve Performans Analizi: Olay Çalışması Örneği, 17.Finans Sempozyumu 23-26 Ekim 2013/Muğla: ss. 130 - 142.

AKTAN, C.C., (2006). Kurumsal Şirket Yönetimi. Sermaye Piyasası Kurulu Kurumsal Araștırmalar Serisi Ankara: Onuray Reklamcılık ve Matbaacilık, ss. 1-34

AYSAN, M. A., (2007). Muhasebe ve Kurumsal Yönetim. Muhasebe ve Finansman Dergisi- MUFAD Journal, Issue 35, ss. 17-24.

BEKTAȘ, H. ve TEKIN, M., (2013).Finansal Oranlar ve Borsa Performans Oranları İlişkisi: İMKB'de İșlem Gören Bankaların Kanonik Korelasyon Analizi. Marmara İ̈B Dergisi, 34(1),ss.317-329.

BDDK, (2013). Bankaların Listesi. http://www.bddk.org.tr/WebSitesi/ turkce/Kuruluslar/Bankalar/Bankalar.aspx $\quad\left[\begin{array}{lllll}18 & \text { Aralık } & 2013 & \text { tarihinde }\end{array}\right.$ erişilmiştir]

BİST, (2013). Kurumsal Yönetim Endeksi. [Çevrimiçi]: http://www.imkb.gov.tr/indexes/stockindexeshome/CorporateGovernanceInd ex.aspx [18 Aralık 2013 tarihinde erișilmiştir].

BROOKS, C., (2008). Introductory Econometrics For Finance,Cambridge University Press, Second Edition.

KALAYCI, Ş., ÇARIKÇI, İ. H. ve GÖK, İ., (2009). Kurumsal YönetimŞirket Performansı İlișkisi: IMKB Kurumsal Yönetim Endeksi Üzerine Ampirik Bir Çalıșma, Alanya İșletme Fakültesi Dergisi 1(1) : ss. 51- 72.

ÇELIK, S. ve AKARIM, Y. D., (2012). Likidite Riski Yönetimi: Panel Veri Analizi ile İMKB Bankacılık Sektörü Üzerine Ampirik Bir Uygulama. Eskişehir Osmangazi Üniversitesi Sosyal Bilimler Dergisi, 13(1),ss.1-17.

ÇONKAR, M. K., ELITAŞ, C. ve ATAR, G., (2011). İMKB Kurumsal Yönetim Endeksi'ndeki Firmaların Finansal Performanslarının TOPSIS 
Ölçümü ve Kurumsal Yönetim Notu İle Analizi, İstanbul Üniversitesi İktisat Fakültesi Mecmuas1, Say1:12, ss. 61(1), ss:81-115.

DAĞLI, H., HASAN, A., ve EYÜBOĞLU, K. (2010). Kurumsal Yönetim Endeksi Performans Değerlendirmesi: Türkiye Örneği. Muhasebe ve Finansman Dergisi, 48(1), ss.18-31.

DALĞAR, H. ve ÇELIKK, İ., (2011). Kurumsal Yönetimin İşletmelerin Finansal Yapısına Etkileri: İMKB Kurumsal Yönetim Endeksi Üzerine Bir İnceleme. Finans Politik ve Ekonomik Yorumlar, 48(557), ss. 99-111.

DEMİREL, E., ATAKIȘí, A. ve ABACIOĞLU, S., (2013). Bankacılık Faaliyet Oranlarının Panel Veri Analizi: Türkiye'deki Kamu, Özel ve Yabanc1 Sermayeli Bankaların Durumu. Muhasebe ve Finansman Dergisi,59. ss.101-112.

DOĞRU, C. (2011). Karlılı̆̆ın Belirleyicileri Analizi: Teori ve Orta Ölçekli Bir Banka Uygulaması. Maliye Finans Yazıları, 25(91). ss.47-85.

EGE, İ., TOPALOĞLU E. E. ve ÖZYAMANOĞLU M., (2013). Finansal Performans İle Kurumsal Yönetim Notları Arasındaki İlişki: BİST Üzerine Bir Uygulama, Akademik Araştırmalar ve Çalışmalar Dergisi 5(9), ss. $100-117$.

GOMPERS, P., ISHII, J. \& METRICK, A., (2003). Corporate Governance And Equity Prices. Quarterly Journal of Economics , 118(1), pp. $107-155$

GÖKÇEN, Z., SÖZÜER, A. ve ARSLANTAȘ, C.C., (2012). Yönetim Kurulu Özellikleri ve Şirket Performansları: İMKB Kurumsal Yönetim ve İMKB 50 Endekslerindeki İşletmelerin Karşılaştırması, İşletme İktisadı Enstitüsü Yönetim Dergisi 23 (72), ss. 77-89.

GUJARATI, D,N., (2004). Basic Econometrics, The McGraw-Hill Co..

GÜÇLÜ, H., (2010). Kurumsal Yönetim Uyum Derecelendirmesi. İstanbul: Ufuk Reklamc1l1k Matbaac1l1k

KAP, (2013). Kamuoyunu Aydinlatma Platformu. http://www.kap.gov.tr/bildirim-sorgulari/finansal-tablolar.aspx $\quad[18$ Aralık 2013 tarihinde erişilmiştir].

KARAMUSTAFA, O., VARICI İ. ve ER B., (2009). Kurumsal Yönetim ve Firma Performansı: İMKB Kurumsal Yönetim Endeksi Kapsamındaki Firmalar Üzerinde Bir Uygulama, Kocaeli Üniversitesi Sosyal Bilimler Enstitüsü Dergisi (17) / 1 : ss. 100 - 119

KARAYEL, M. ve GÖK, İ.Y., (2009). Kurumsal Yönetim- Performans İlișkisi: İMKB Kurumsal Yönetim Endeksine Kayıtlı Halka Açık Şirketlerde Bir Araștırma. Akademik Fener Dergisi, Sayı:12, ss. 9-28. 
KILIÇ, S., (2011). İMKB Kurumsal Yönetim Endeksine Dahil Olan Şirketlerin Getiri Performanslarının Ölçülmesi. Finans Politik ve Ekonomik Yorumlar, 48(552), ss. 45-58.

OECD (2004), Principles of Corporate Governance, www.oecd.org

SAKARYA, B. ve KAYA, Y., (2013). Türk Bankacıllk Sektöründe Katılım ve Mevduat Bankaların Performans Farklılaşması. Ey International Congress On Economics I "Europe And Global Economic Rebalancing, paper number: 215, ss. 1-13.

SAKARYA, Ş., (2011). İMKB Kurumsal Yönetim Endeksi Kapsamındaki Şirketlerin Kurumsal Yönetim Derecelendirme Notu ve Hisse Senedi Getirileri Arasındaki İlişkinin Olay Çalışması Yöntemi ile Analizi. ZKÜ Sosyal Bilimler Dergisi, 7(13), ss.147-162.

SHERMAN, H., (2004). Corporate Governance Rating. Corporate Governance : An International Review, 12(1), pp. 5-7

SHLEIFER, A., \& VISHNY. R.W., (1997). A Survey of Corporate Governance. The Journal of Finance, Issue 52(2), pp 737-783

ŞENGÜR, E. D. ve PÜSKÜL, A.S.Ö., (2011). İMKB Kurumsal Yönetim Endeksindeki Șirketlerin Yönetim Kurulu Yapısı Ve İșletme Performansının Değerlendirilmesi. Dumlupınar Üniversitesi Sosyal Bilimler Dergisi, Sayı:12, ss. 33-50.

TBB, (1999). Türkiye Bankalar Birliği Bankacılık ve Araştırma Grubu, Basel Bankacılık Gözetim Komitesi, 1999. Bankalarda Kurumsal Yönetim. [Çevrimiçi]http://www.google.com.tr/url? sa $=\mathrm{t} \& \mathrm{rct}=\mathrm{j} \& \mathrm{q}=\&$ esrc $=\mathrm{s} \&$ source $=$ web\&cd $=1 \&$ ved $=0 \mathrm{CDEQFjAA} \& u r l=\mathrm{http} \% 3 \mathrm{~A} \% 2 \mathrm{~F} \% 2 \mathrm{Fwww} \cdot \operatorname{tbb}$. org.tr $\% 2 \mathrm{~F}$ Dosyalar\%2FArastirma_ve_Raporlar\%2F2kurumsal.doc\&ei=ilcaUbfBHen3 4QSwvYHYBQ\&usg=AFQjCNHgPbz7jZI9opoeF32JKLrZz47J1A\&bvm=b v.42261806,d.bGE [12 Şubat 2013 tarihinde erişilmiştir]

TKYD, (Eylül 2011). Ekonomi Gazeteciliği İçin Kurumsal Yönetim El Kitabı. İstanbul: Pasifik Ofset

TÜSİAD, (2002). Kurumsal Yönetim En iyi Uygulama Kodu: Yönetim Kurulunun Yapıs1 ve İşleyişi, TS/ŞiR/02-192/2002, http://www.tusiad.org/02.htm

YENICE, S. ve DÖLEN, T., (2013). İMKB'de İșlem Gören Firmaların Kurumsal Yönetim İlkelerine Uyumunun Firma Değeri Üzerine Etkisi. Uluslararası Yönetim İktisat ve İșletme Dergisi, 9(19), ss. 199-214.

YILDIZ, S., (2010). İşletme Performansının Ölçümü Üzerine Bankacılık Sektöründe Bir Araştırma. Erciyes Üniversitesi İktisadi ve İdari Bilimler Fakültesi Dergisi, 36, ss.179-193. 